\title{
GAMBARAN PEROKOK DAN ANGKA KEJADIAN LESI MUKOSA MULUT DI DESA MONSONGAN KECAMATAN BANGGAI TENGAH
}

\author{
${ }^{1}$ Rizki Mulyana Djokja \\ ${ }^{2}$ B. S. Lampus \\ ${ }^{3}$ Christy Mintjelungan
}

\author{
${ }^{1}$ Kandidat Skripsi Program Studi Kedokteran Gigi Fakultas Kedokteran \\ Universitas Sam Ratulangi Manado \\ ${ }^{2}$ Bagian Ilmu Kesehatan Masyarakat Fakultas Kedokteran Universitas Sam Ratulangi Manado \\ ${ }^{3}$ Program Studi Kedokteran Gigi Universitas Sam Ratulangi Manado \\ Email: rizki26.dentist@gmail.com
}

\begin{abstract}
Nowadays, smokers may be encountered from different social class, status, and different age groups. This is because it is very easy to get cigarettes. Many studies demonstrated the effects of smoking are influenced by the large number of cigarettes, duration of smoking, type of cigarettes smoked even depth of smoke may cause some disorders in the oral cavity. Purpose of this study was to determine the smokers and the incidence of oral mucosal lesions in the Monsongan village in Banggai district. This research method is descriptive with cross sectional study approach. Samples in this study are smokers in the Monsongan village. Calculations based on preliminary survey results obtained 264 people as smoking population and 80 people were selected as research sample. Results showed that from 80 research sample were examined, the incidence of oral mucosal lesions most often found in the sample with a smoking duration more than 20 years were 51 people (63.75\%). Incidence of oral mucosal lesions most often found in smokers with number of cigarettes smoked per day 10-20 rods were 44 people (55\%). Incidence of oral mucosal lesions most often found in cigarette smokers were 65 people (81.25\%).
\end{abstract}

Key words: smoking, oral mucosal lesions.

\begin{abstract}
Abstrak: Perokok saat ini bisa kita jumpai dari berbagai kelas sosial, status serta kelompok umur yang berbeda. Hal ini dikarenakan rokok sangat mudah untuk didapatkan. Banyak penelitian yang membuktikan efek dari merokok yang dipengaruhi oleh banyaknya jumlah rokok, lama merokok, jenis rokok bahkan dalamnya hisapan merokok dapat menimbulkan beberapa kelainan rongga mulut. Tujuan dari penelitian ini ialah untuk mengetahui bagaimana gambaran perokok dan angka kejadian lesi pada mukosa mulut di desa Monsongan kecamatan Banggai tengah. Metode penelitian ini bersifat deskriptif dengan pendekatan studi potong lintang. Sampel dalam penelitian ini yaitu masyarakat perokok di desa Monsongan. Berdasarkan perhitungan survei awal didapatkan hasil populasi perokok sebanyak 264 orang dan yang menjadi sampel penelitian berjumlah 80 orang. Hasil penelitian menunjukkan dari 80 orang subjek penelitian yang diperiksa, kejadian lesi mukosa mulut paling banyak dijumpai pada lama merokok > 20 tahun sebanyak 51 orang (63.75\%). Kejadian lesi mukosa mulut paling banyak dijumpai pada perokok dengan jumlah rokok yang dihisap 10-20 batang per hari sebanyak 44 orang (55\%). Kejadian lesi mukosa mulut paling banyak dijumpai pada perokok yang merokok dengan jenis rokok putih sebanyak 65 orang (81.25\%).
\end{abstract}

Kata kunci: perokok, lesi mukosa mulut. 
Salah satu strategi Pembangunan Kesehatan Nasional dalam rangka menuju Indonesia Sehat 2010 adalah menerapkan pembangunan kesehatan yang berwawasan Perilaku Hidup Bersih dan Sehat (PHBS). Menurut peneliti Universitas Wageningen, ada empat gaya hidup sehat yang harus dijalankan yaitu berhati-hati dengan makanan (diet), menghindari alkohol, olahraga dan menghentikan kebiasaan merokok. ${ }^{1}$

Menurut World Health Organization (WHO) diperkirakan bahwa terdapat 300 juta perokok di negara maju, sedangkan di negara berkembang mendekati 3 kali lipat yaitu sebanyak 800 juta. $^{2}$ WHO melaporkan bahwa Indonesia merupakan salah satu dari 5 negara yang terbanyak perokoknya di dunia. $^{3}$ Indonesia merupakan salah satu negara berkembang yang memiliki tingkat konsumsi rokok dan produksi rokok yang tinggi. ${ }^{4}$ Menurut data Riset Kesehatan Dasar (Riskesdas) 2007 prevalensi perokok di Indonesia sebanyak 29,2\% dan pada data Riskesdas 2012 prevalensi perokok di Indonesia telah menjadi 34,7\%. Hal ini menunjukkan adanya peningkatan prevalensi perokok di Indonesia.

Perokok berasal dari berbagai kelas sosial, status serta kelompok umur yang berbeda. ${ }^{5}$ Bahkan oleh sebagian orang rokok sudah menjadi kebutuhan hidup yang tidak bisa ditinggalkan dalam kehidupan seharihari. ${ }^{6}$ Menurut data Riskesdas 2010, prevalensi perokok di daerah pedesaan lebih banyak dari pada yang ada perkotaan, prevalensi perokok pada petani, nelayan dan buruh pun lebih besar dibanding yang tidak bekerja, sekolah, pegawai dan wiraswasta.

Rongga mulut ialah bagian tubuh yang pertama kali terpapar asap rokok sehingga sangat mudah terpapar efek rokok karena merupakan tempat terjadinya penyerapan zat hasil pembakaran rokok yang utama.,8 Beberapa kelainan rongga mulut yang ditimbulkan atau sebagai efek dari merokok yaitu penyakit periodontal, leukoplakia, stomatitis nikotina, smokeless tobacco keratosis, fibrosis submukosa, hairy tongue dan keganasan rongga mulut. ${ }^{2}$

Desa Monsongan berada di kecamatan Banggai Tengah kabupaten Banggai
Kepulauan Provinsi Sulawesi Tengah. Masyarakat Desa Monsongan memiliki profesi sebagai petani dan nelayan.Sebagian besar masyarakat disana merupakan masyarakat perokok. Belum tersedianya fasilitas dan pelayanan kesehatan gigi dan mulut di desa tersebut menyebabkan masyarakat kurang peduli terhadap kesehatan gigi dan mulutnya. Puskesmas pembantu ialah satusatunya fasilitas pelayanan kesehatan yang tersedia di Desa Monsongan dengan tenaga kesehatannya mantri dan bidan. Desa Monsongan Kecamatan Banggai Tengah sendiri belum pernah dilakukan penelitian mengenai lesi pada mukosa mulut akibat dari kebiasaan merokok.

\section{Metode penelitian}

Penelitian ini merupakan penelitian yang bersifat deskriptif dengan pendekatan studi potong lintang (cross sectional study) dilaksanakan di Desa Monsongan Kecamatan Banggai Tengah pada bulan Juli-Agustus 2012.Populasi dalam penelitian ini ialah seluruh pria yang tinggal diDesa Monsongan Kecamatan Banggai Tengah. Berdasarkan profil desa yang ada di Kantor Desa Monsongan Kecamatan Banggai Tengah pria dengan usia lebih dari 15 tahun sebanyak 692 orang. Menurut data Riskesdas 2010 prevalensi perokok usia di Sulawesi Tengah sebanyak 38,2 \%. Berdasarkan data tersebut populasi perokok dapat kita ketahui melalui hasil kali antara jumlah priausia lebih dari 15 tahun yang tinggal di desa Monsongan dengan prevalensi perokok di Sulawesi Tengah, sehingga didapatkan hasil populasi perokok sebanyak 264 orang.

Kriteria inklusi yaitu memiliki kebiasaan merokok sedikitnya 1 batang per hari selama sekurang-kurangnya 1 tahun sampai pada saat penelitian dilakukan, bersedia menjadi subjek penelitian, dapat berkomunikasi dengan baik, bersifat kooperatif dalam pemeriksaan. Kriteria ekslusi yaitu tidak bisa membuka mulut dan tidak bersedia dijadikan subjek penelitian. Besar sampel dalam penelitian ini ditentukan dengan menggunakan Rumus Slovin sehingga didapatkan besar sampel sebanyak 80 orang. 
40 Jurnal e-GiGi (eG), Volume 1, Nomor 1, Maret 2013, hlm. 38-44

Alat dan bahan yang digunakan dalam penelitian ini yaitu: sarung tangan, masker, nierbekken, kaca mulut, lampu senter, kamera, dan formulir pemeriksaan. Tahapan-tahapan dalam penelitian yaitu:

1. Subjek penelitian dimintakan ijin tertulis berupa informed consent sebagai persetujuan bahwa subjek bersedia untuk dilakukan pengambilan data dan pemeriksaan klinis rongga mulut

2. Pengambilan data dilakukan dengan mengisi formulir pemeriksaan. Selanjutnya dilakukan pemeriksaan klinis rongga mulut

3. Sebelum melakukan pemeriksaan, peneliti memakai sarung tangan dan masker terlebih dahulu

4. Subjek diperiksa dalam keadaan duduk menghadap sumber cahaya (dalam hal ini dapt dibantu dengan menggunakan cahaya lampu senter jika penerangan ruangan tidak memudahkan operator melihat keadaan mulut subjek dengan dengan jelas)

5. Subjek diperiksa keadaan mulut dan jaringan disekitarnya terkait dengan adanya lesi-lesi pada mukosa mulut

6. Hasil pemeriksaan klinis dicatat pada formulir pemeriksaan

\section{HASIL PENELITIAN}

Karakteristik subjek penelitian didistribusikan berdasarkan kelompok umur, lama merokok, jumlah rokok yang dihisap per hari, dan jenis rokok. Distribusi subjek penelitian berdasarkan kelompok umur dapat dilihat pada Tabel 1.

Distribusi subjek penelitian berdasarkan kelompok umur dengan jumlah perokok tertinggi yaitu subjek berusia 35-44 tahun sebanyak 23 orang (28,75\%).

Distribusi frekuensi responden berdasarkan tingkat pendidikan dapat dilihat pada Tabel 2.

Distribusi subjek penelitian berdasarkan tingkat pendidikan. Terlihat bahwa sebagian besar tingkat pendidikan subjek yaitu tamat sekolah dasar sebanyak 50 orang (62,5\%), sekolah menengah atas sebanyak 15 orang $(18,8 \%)$, sekolah menengah perta- ma sebanyak 10 orang (12,5\%), tidak sekolah sebanyak 3 orang (3,8\%), dan perguruan tinggi sebanyak 2 orang (2,5\%).

Distribusi frekuensi responden berdasarkan pekerjaan dapat dilihat pada Tabel 3.

Distribusi subjek penelitian berdasarkan pekerjaan. Terlihat bahwa sebagian besar pekerjaan subjek penelitian yaitu petani sebanyak 62 orang $(77,5 \%)$, nelayan sebanyak 16 orang $(20,0 \%)$, dan pegawai negeri sipil sebanyak 2 orang (2,5\%).

Distribusi subjek penelitian berdasarkan lama merokok dapat dilihat pada Tabel 4.

Tabel 1. Distribusi subjek penelitian berdasarkan kelompok umur

\begin{tabular}{ccc}
\hline Umur (tahun) & n (jumlah) & \% (persentase) \\
\hline $15-24$ & 11 & 13,75 \\
$25-34$ & 16 & 20 \\
$35-44$ & 23 & 28,75 \\
$45-54$ & 17 & 21,25 \\
$55-64$ & 7 & 8,75 \\
$65-74$ & 5 & 6,25 \\
$>75$ & 1 & 1,25 \\
Total & 80 & 100 \\
\hline
\end{tabular}

Tabel 2. Distribusi subjek penelitian berdasarkan tingkat pendidikan

\begin{tabular}{lcc}
\hline \multicolumn{1}{c}{ Tingkat pendidikan } & n & \% \\
\hline Tidak sekolah & 3 & 3,8 \\
Tamat SD & 50 & 62,5 \\
Tamat SMP & 10 & 12,5 \\
Tamat SMA & 15 & 18,8 \\
Tamat Perguruan tinggi & 2 & 2,5 \\
Total & 80 & 100 \\
\hline
\end{tabular}

Tabel 3. Distribusi subjek penelitian berdasarkan pekerjaan

\begin{tabular}{lcc}
\hline \multicolumn{1}{c}{ Pekerjaan } & n & \% \\
\hline Petani & 62 & 77,5 \\
Nelayan & 16 & 20 \\
Pegawai negeri sipil & 2 & 2,5 \\
$\quad$ Total & 80 & 100 \\
\hline
\end{tabular}


Tabel 4. Distribusi subjek penelitian berdasarkan lama merokok

\begin{tabular}{ccc}
\hline Lama merokok & n & \% \\
\hline 1 -10 tahun & 15 & 18,75 \\
10-20 tahun & 12 & 15 \\
$>$ 20 tahun & 53 & 66,25 \\
Total & 80 & 100 \\
\hline
\end{tabular}

Distribusi subjek penelitian berdasarkan lama merokok menunjukkan perokok terbanyak ialah yang merokok > 20 tahun sebanyak 53 orang $(66,25 \%)$.

Distribusi frekuensi responden berdasarkan jumlah rokok yang dihisap perhari dapat dilihat pada Tabel 5.

Tabel 5. Distribusi subjek penelitian berdasarkan jumlah rokok yang dihisap perhari

\begin{tabular}{ccc}
\hline $\begin{array}{c}\text { Jumlah rokok } \\
\text { (perhari) }\end{array}$ & $\mathbf{n}$ & $\mathbf{\%}$ \\
\hline$<10$ batang & 14 & 17,5 \\
$10-20$ batang & 52 & 65 \\
$>20$ batang & 14 & 17,5 \\
Total & 80 & 100 \\
\hline
\end{tabular}

Distribusi subjek penelitian berdasarkan jumlah rokok yang dihisap perhari menunjukkan perokok terbanyak ialah yang merokok antara 10-20 batang per hari sebanyak 52 orang (65\%).

Distribusi subjek penelitian berdasarkan jenis rokok dapat dilihat pada Tabel 6.

Tabel 6. Distribusi subjek penelitian berdasarkan jenis rokok

\begin{tabular}{lcc}
\hline \multicolumn{1}{c}{ Jenis rokok } & n & \% \\
\hline Rokok putih & 77 & 96,25 \\
Rokok kretek & 0 & 0 \\
Rokok campuran & 3 & 3,75 \\
$\quad$ Total & 80 & 100 \\
\hline
\end{tabular}

Distribusi subjek penelitian berdasarkan jenis rokok menunjukkan perokok terbanyak ialah yang merokok dengan jenis rokok putih sebanyak 77 orang $(96,25 \%)$.

Pemeriksaan lesi mukosa mulut dilakukan terhadap semua subjek yang diteliti dengan cara memeriksa keadaan rongga mulut. Distribusi kejadian lesi mukosa mulut yang ditemukan pada subjek penelitian dapat dilihat pada Tabel 7.

Tabel 7. Distribusi kejadian lesi mukosa mulut pada subjek penelitian

\begin{tabular}{lcc}
\hline Kejadian lesi mukosa mulut & $\mathbf{n}$ & $\mathbf{\%}$ \\
\hline Ada & 68 & 85 \\
Tidak & 12 & 15 \\
Total & 80 & 100 \\
\hline
\end{tabular}

Data diatas menunjukkan bahwa pada subjek penelitian terdapat 68 orang (85\%) yang memiliki lesi mukosa mulut dan 12 orang (15\%) tidak ada lesi mukosa mulut.

Distribusi kejadian lesi mukosa mulut berdasarkan lama merokok dapat dilihat pada Tabel 8.

Tabel 8. Distribusi kejadian lesi mukosa mulut berdasarkan lama merokok

\begin{tabular}{|c|c|c|c|c|c|c|}
\hline \multirow{3}{*}{$\begin{array}{c}\text { Lama } \\
\text { merokok }\end{array}$} & \multicolumn{4}{|c|}{$\begin{array}{c}\begin{array}{c}\text { Kejadian lesi mukosa } \\
\text { mulut }\end{array} \\
\end{array}$} & \multicolumn{2}{|c|}{ Total } \\
\hline & \multicolumn{2}{|c|}{ Ada } & \multicolumn{2}{|c|}{ Tidak } & \multirow[b]{2}{*}{$\mathrm{n}$} & \multirow[b]{2}{*}{$\%$} \\
\hline & $\mathrm{n}$ & $\%$ & $\mathrm{n}$ & $\%$ & & \\
\hline 1-10 tahun & 7 & 8.75 & 8 & 10 & 15 & 18.75 \\
\hline 10-20 tahun & 10 & 12.5 & 2 & 2.5 & 12 & 15 \\
\hline$>20$ tahun & 51 & 63.75 & 2 & 2.5 & 53 & 66.25 \\
\hline Total & 68 & 85 & 12 & 15 & 80 & 100 \\
\hline
\end{tabular}

Tabel 8 menunjukkan distribusi kejadian lesi mukosa mulut berdasarkan lama merokok. Data pada tabel 8 menunjukkan bahwa dari 15 orang yang merokok 1-10 tahun, sebanyak 7 orang (8.75\%) memiliki lesi mukosa mulut dan 8 orang (10\%) tidak ada lesi mukosa mulut. Dari 12 orang yang merokok 10-20 tahun, sebanyak 10 orang (12.5\%) memiliki lesi mukosa mulut dan 2 orang (2.5\%) tidak ada lesi mukosa mulut. Dari 53 orang yang 
42 Jurnal e-GiGi (eG), Volume 1, Nomor 1, Maret 2013, hlm. 38-44

merokok > 20 tahun, sebanyak 51 orang (63.75\%) memiliki lesi mukosa mulut dan 2 orang (2.5\%) tidak ada lesi mukosa mulut.

Distribusi kejadian lesi mukosa mulut berdasarkan jumlah rokok yang dihisap dapat dilihat pada Tabel 9.

Tabel 9. Distribusi kejadian lesi mukosa mulut berdasarkan jumlah rokok yang dihisap per hari

\begin{tabular}{|c|c|c|c|c|c|c|}
\hline \multirow{3}{*}{$\begin{array}{c}\text { Jumlah rokok } \\
\text { yang } \\
\text { dihisap per hari }\end{array}$} & \multicolumn{4}{|c|}{$\begin{array}{c}\text { Kejadian lesi mukosa } \\
\text { mulut }\end{array}$} & \multicolumn{2}{|c|}{ Total } \\
\hline & \multicolumn{2}{|c|}{ Ada } & \multicolumn{2}{|c|}{ Tidak } & & \\
\hline & $\mathrm{n}$ & $\%$ & $\mathrm{n}$ & $\%$ & $\mathrm{n}$ & $\%$ \\
\hline$<10$ batang & 11 & 13.75 & 3 & 3.75 & 14 & 17.5 \\
\hline 10-20 batang & 44 & 55 & 8 & 10 & 52 & 65 \\
\hline > 20 batang & 13 & 16.25 & 1 & 1.25 & 14 & 17.5 \\
\hline Total & 68 & 85 & 12 & 15 & 80 & 100 \\
\hline
\end{tabular}

Tabel 9 menunjukkan distribusi kejadian lesi mukosa mulut berdasarkan jumlah rokok yang dihisap per hari. Data pada tabel 9 menunjukkan bahwa dari 14 orang yang merokok $<10$ batang per hari, sebanyak 11 orang (13.75\%) memiliki lesi mukosa mulut dan 3 orang (3.75\%) tidak ada lesi mukosa mulut. Dari 52 orang yang merokok 10-20 batang per hari, sebanyak 44 orang (55\%) memiliki lesi mukosa mulut dan 8 orang (10\%) tidak ada lesi mukosa mulut. Dari 14 orang yang merokok > 20 batang per hari, sebanyak 13 orang (16.25\%) memiliki lesi mukosa mulut dan 1 orang (1.25\%) tidak ada lesi mukosa mulut.

Distribusi kejadian lesi mukosa mulut berdasarkan jenis rokok dapat dilihat pada Tabel 10.

Tabel 10. Distribusi kejadian lesi mukosa mulut berdasarkan jenis rokok

\begin{tabular}{lccccccc}
\hline \multirow{2}{*}{ Jenis rokok } & \multicolumn{4}{c}{ Kejadian lesi } & \multicolumn{2}{c}{ Total } \\
\cline { 2 - 5 } & \multicolumn{3}{c}{ Ada } & \multicolumn{2}{c}{ Tidak } & & \\
\cline { 2 - 5 } & $\mathrm{n}$ & $\%$ & $\mathrm{n}$ & $\%$ & $\mathrm{n}$ & $\%$ \\
\hline Rokok putih & 65 & 81.25 & 12 & 15 & 77 & 96.25 \\
Rokok kretek & 0 & 0 & 0 & 0 & 0 & 0 \\
Rokok & & & & & & \\
campuran & 3 & 3.75 & 0 & 0 & 3 & 3.75 \\
Total & 68 & 85 & 11 & 15 & 80 & 100 \\
\hline
\end{tabular}

Tabel 10 menunjukkan distribusi kejadian lesi mukosa mulut berdasarkan jenis rokok. Data pada tabel 10 menunjukkan dari 77 orang yang merokok dengan jenis rokok putih, sebanyak 65 orang (81.25\%) memiliki lesi mukosa mulut dan 12 orang (15\%) tidak ada lesi mukosa mulut. Dari 3 orang yang merokok dengan jenis rokok campuran, semuanya memiliki lesi mukosa mulut.

\section{BAHASAN}

Umur subjek penelitian dikelompokkan berdasarkan pengelompokkan umur yang dilakukan oleh Riskesdas 2010. Berdasarkan hasil penelitian, pada tabel 1 menunjukan distribusi perokok paling banyak pada kelompok umur 35-44 tahun sebesar 28.8\% . Namun hasil ini berbeda dengan hasil penelitian yang dilakukan Riskesdas tahun 2010.Data Riskesdas 2010 menunjukkan umur 45-54 tahun merupakan kelompok umur yang paling banyak merokok sebesar $38.2 \%$.Hal ini dapat terjadi karena adanya perbedaan distribusi umur subyek penelitian yang diteliti. Jumlah subjek penelitian pada Riskesdas lebih banyak dan mencakup wilayah yang luas., 9

Karakteristik perokok pada penelitian ini paling banyak pada tingkat pendidikan tamat Sekolah Dasar sebesar 62.5\%. Hal ini berbeda dengan hasil penelitian yang dilakukan oleh Riskesdas 2010 yang menunjukkan persentase terbanyak perokok ialah dengan tingkat pendidikan tamat SD sebanyak 30,4\%. Tingkat pendidikan yang rendah dari masyarakat dapat mempengaruhi pengetahuan mengenai bahaya merokok terhadap kesehatan rongga mulut.

Berdasarkan pekerjaan, hasil penelitian ini menunjukkan karakteristik perokok paling banyak memiliki pekerjaan sebagai petani sebesar $77.5 \%$. Hal ini berbeda dengan penelitian yang dilakukan oleh Riskesdas 2010 yang menunjukkan persentase terbanyak perokok ialah sebesar $42.5 \%$ pada petani, nelayan atau buruh.

Berdasarkan lama merokok, pada penelitian ini paling banyak perokok dengan lama merokok $>20$ tahun yaitu sebesar $66.25 \%$. Hasil ini berbeda dengan penelitian 
yang dilakukan oleh Komala yang menunjukkan jumlah perokok paling banyak dengan lama merokok 11-20 tahun sebesar $37.3 \%{ }^{8}$

Perokok pada subjek penelitian ini termasuk dalam kategori perokok sedang, dengan jumlah rokok yang dihisap sebanyak $10-20$ batang per hari sebesar $65 \%$. Hasil ini berbeda dengan penelitian yang dilakukan Syahrir yakni paling banyak ditemukan perokok yang merokok 10-20 batang per hari sebesar $59.1 \%{ }^{9}$

Di Indonesia 80-95\% memilih jenis rokok kretek untuk dikonsumsi. ${ }^{9}$ Namun berbeda dengan hasil penelitian ini, yaitu subjek penelitian paling banyak ditemukan merokok dengan jenis rokok putih sebesar 96.25\%. Hal ini karena di desa Monsongan harga rokok putih lebih murah dibanding rokok kretek. Begitu juga dengan hasil penelitian dari Sitepu pada mahasiswa fakultas matematika dan ilmu pengetahuan alam Universitas Sumatera Utara, walaupun persentasenya lebih sedikit dibandingkan dengan hasil penelitian ini, jenis rokok yang paling banyak dikonsumsi ialah rokok putih sebesar $45.1 \%{ }^{11}$

Berdasarkan lama merokok dapat dilihat pada tabel 8, lama merokok >20 tahun paling banyak ditemukan lesi mukosa mulut yaitu sebanyak 51 orang (63.75\%). Hal ini disebabkan karena terpaparnya asap rokok pada mukosa mulut, sehingga semakin lama seseorang merokok, maka semakin besar pula kemungkinan terjadinya lesi mukosa mulut. Penelitian ini didukung dengan Nadeem $\mathrm{M}$, et al di Pakistan, menunjukkan bahwa adanya hubungan antara lama merokok dengan distribusi pigmentasi melanin intra oral. Kondisi ini disebabkan oleh efek panas dari asap tembakau pada jaringan mulut atau efek langsung dari nikotin yang merangsang melanocytes yang terletak disepanjang selsel basal epitel untuk menghasilkan melanosomes sehingga mengakibatkan deposisi peningkatan melanin. ${ }^{12}$

Berdasarkan jumlah rokok yang dihisap per hari dapat dilihat pada tabel 9, lesi mukosa mulut paling banyak ditemukan pada perokok dengan jumlah rokok yang dihisap 10-20 batang per hari yaitu sebanyak 44 orang (55\%). Hasil ini didukung dengan penelitian yang dilakukan oleh Kang di Medan bahwa jumlah rokok yang dihisap per hari berpengaruh terhadap terjadinya stomatitis nikotina. ${ }^{13}$

Berdasarkan jenis rokok dapat dilihat pada tabel 10, lesi mukosa mulut paling banyak ditemukan pada jenis rokok putih yaitu sebanyak 65 orang (81.25\%).Hal ini dikarenakan paling banyak ditemukan perokok dengan yang merokok dengan jenis rokok putih.Namun bisa kita lihat juga pada tabel 10 lesi mukosa mulut terdapat pada seluruh perokok dengan jenis rokok campuran.Subjek penelitian yang merokok dengan jenis rokok campuran ialah perokok yang merokok dengan rokok kretek dan rokok putih.Penelitian yang dilakukan Susana, dkk menunjukkan paling besar ditemukan nikotin pada jenis rokok kretek. Karena pada rokok kretek tidak dilengkapi filter yang berfungsi mengurangi asap yang keluar dari rokok seperti yang terdapat pada jenis rokok putih. ${ }^{14}$ Sehingga ditemukan seluruh subjek penelitian pada perokok campuran memiliki lesi mukosa mulut karena efek langsung dari nikotin yang diterima perokok campuran lebih besar dari pada perokok yang hanya merokok dengan jenis rokok putih.

Berdasarkan angka kejadian lesi mukosa mulut, dari 80 orang subjek penelitian terdapat 85\%yang memiliki lesi mukosa mulut dan 15\% tidak memiliki lesi mukosa mulut. Hal ini disebabkanrongga mulut merupakan bagian tubuh yang pertama kali terpapar asap rokok, sehingga mukosa mulut menjadi bagian yang sangat mudah terpapar efek rokok dan menjadi tempat penyerapan zat hasil pembakaran rokok yang utama.,8 Efek merokok yang timbul dipengaruhi oleh banyaknya jumlah rokok yang dihisap, lama merokok, jenis rokok yang dihisap, bahkan berhubungan dengan dalamnya hisapan rokok yang dilakukan. ${ }^{7,9,10}$

\section{SIMPULAN}

1. Lesi mukosa mulut paling banyak 
44 Jurnal e-GiGi (eG), Volume 1, Nomor 1, Maret 2013, hlm. 38-44

dijumpai pada lama merokok $>20$ tahun sebanyak 51 orang $(63.75 \%)$.

2. Lesi mukosa mulut paling banyak dijumpai pada jumlah rokok yang dihisap 10-20 batang per hari sebanyak 44 orang (55\%).

3. Lesi mukosa mulut paling banyak dijumpai pada jenis rokok campuran sebanyak 65 orang (81.25\%).

\section{DAFTAR PUSTAKA}

1. Fawzani N, Triratnawati A. Terapi berhenti merokok (studi kasus 3 perokok berat). Makara Kesehatan [serial on the internet]. Juni 2005 [cited 2012 Jun 17]; 9(1):15-22. Available from: journal.ui.ac. id/health/article/download/ 342/338.

2. Revianti S. Pengaruh radikal bebas pada rokok terhadap timbulnya kelainan di rongga mulut. DENTA Jurnal Kedokteran Gigi FKG-UHT. Feb 2007; 1:85-9.

3. Suryawati R. Rokok sebagai faktor predisposisi terjadinya leukoplakia. Skripsi USU [serial on the internet]. 2009 [cited 2012 June 24]; h.1. Available from: http://repository.usu.ac.id/bitstream/123456 789/25096/4/ Chapter\%20I.pdf.

4. Nurcahyani FH, Bustamam N, Diandini R. Hubungan antara kebiasaan merokok dan kejadian hipertensi di layanan kesehatan cuma-cuma ciputat. Bina Widya [serial on the internet]. Juni 2011 [cited 2012 Jun 7]; 22(4):185-190. Available from: http://www.library.upnvj.ac.id/pdf/ artikel/Artikel\%20Majalah/Bina\%20Widya /Vol.22-No.4-Juni2011/185-190.pdf.

5. Nasution KI. Perilaku merokok pada remaja. Makalah USU [serial on the internet]. 2008 [cited 2012 June 24]; h.5-9. Available from: http://library.usu.ac.id/ download/fk/132316815.pdf.

6. Jaya M. Pembunuh berbahaya itu bernama rokok. Yogyakarta: Riz'ma; 2009. h.148,49-50.

7. Kusuma ARP. Pengaruh merokok terhadap kesehatan gigi dan rongga mulut. Majalah Ilmiah Sultan Agung [serial on the internet]. [cited 2012 Mei 4]. Available from:http://journal.unissula.ac.id/majalahil miahsultanagung/ article/download/20/20.

8. Komala W. Hubungan kebiasaan merokok dengan terjadinya hairy tongue di kelurahan Indra Kasih Kecamatan Medan Tembung. Skripsi USU [serial on the internet]. 2010 [cited 2012 June 18]; h.1-2. Available from: http://repository.usu.ac.id/bitstream/ 123456789/21669/5/Chapter\%20I.pdf.

9. Syahrir TMR. Hubungan kebiasaan merokok dengan kelainan jaringan lunak mulut di kalangan penarik becak di Kotamadya Medan. Skripsi USU [serial on the internet]. 2008 [cited 2012 June 24]; h.2-3,8-16. Available from: http:// repository.usu.ac.id/bitstream/123456789/2 5307/5/Chapter\%20I.pdf.

10. Badan Penelitian dan Pengembangan Kesehatan Kementerian Kesehatan Republik Indonesia. Riset Kesehatan Dasar. [serial on the internet]. 2010 [cited 2012 Apr 13]. Available from: URL:http://www.riskesdas.litbang.depkes.g o.id/download/TabelRiskesdas2010.pdf.

11. Sitepu LS. Hubungan kebiasaan merokok terhadap terjadinya smoker's melanosis di kalangan mahasiswa Fakultas Matematika dan Ilmu Pengetahuan Alam Universitas Sumatera Utara. Skripsi USU [serial on the internet]. 2010 [cited 2012 June 18]; h.7-9. Available from: http://repository.usu.ac.id/ bitstream/123456789/25307/5/Chapter\%20 I.pdf

12. Nadeem $M$, Shafique $R$, Yaldram $A$, dkk. Intraoral distribution of oral melanosis and cigarette smoking in a Pakistan population. International journal of dental clinics [serial on the internet]. 2011 [cited 2012 Oct 16]; 3(1): 25-28. Available from: http://www.researchgate. net/publication/230691787_Intraoral_distri bution_of_oral_melanosis_and_cigarette_s moking_in_a_Pakistan_population.

13. Kang KZ. Hubungan kebiasaan merokok dengan terjadinya stomatitis nikotina pada pegawai non-akademik Universitas Sumatera Utara. Skripsi USU [serial on the internet]. 2012 [cited 2012 Dec 12]. Available from: http://repository.usu.ac.id/ handle/123456789/33565.

14. Susanna D, Hartono B, Fauzan $H$. Penentuan Kadar Nikotin dalam Asap Rokok. Makara Kesehatan [serial on the internet]. Desember 2003 [cited 2013 Apr 1]; 7(2):38-41. Available from: http:// repository.ui.ac.id/dokumen/lihat/75.pdf. 